\title{
Modeling spatial patterns of saturated areas: A comparison of the topographic wetness index and a dynamic distributed model
}

\author{
T. Grabs ${ }^{a, *}$, J. Seibert ${ }^{\mathrm{a}, \mathrm{b}}$, K. Bishop ${ }^{\mathrm{c}}$, H. Laudon ${ }^{\mathrm{d}}$ \\ a Department of Physical Geography and Quaternary Geology, Stockholm University, SE-106 91 Stockholm, Sweden \\ ${ }^{\mathrm{b}}$ Department of Geography, University of Zurich, CH-8057 Zurich, Switzerland \\ ${ }^{\mathrm{c}}$ Department of Aquatic Sciences and Assessment, Swedish University of Agricultural Sciences, Box 7050, SE-750 07 Uppsala, Sweden \\ ${ }^{\mathrm{d}}$ Department of Forest Ecology and Management, Swedish University of Agricultural Sciences, SE-901 83 Umeå, Sweden
}

\section{A R T I C L E I N F O}

\section{Article history:}

Received 29 August 2008

Received in revised form 20 March 2009

Accepted 31 March 2009

This manuscript was handled by P. Baveye, Editor-in-Chief, with the assistance of Marco Borga, Associate Editor

\section{Keywords:}

Topographic wetness index

Distributed hydrological model

Spatial patterns

Saturated areas

Wetlands

Landscape analysis

\begin{abstract}
S U M M A R Y
Topography is often one of the major controls on the spatial pattern of saturated areas, which in turn is a key to understanding much of the variability in soils, hydrological processes, and stream water quality. The topographic wetness index (TWI) has become a widely used tool to describe wetness conditions at the catchment scale. With this index, however, it is assumed that groundwater gradients always equal surface gradients. To overcome this limitation, we suggest deriving wetness indices based on simulations of distributed catchment models. We compared these new indices with the TWI and evaluated the different indices by their capacity to predict spatial patterns of saturated areas. Results showed that the modelderived wetness indices predicted the spatial distribution of wetlands significantly better than the TWI. These results encourage the use of a dynamic distributed hydrological model to derive wetness index maps for hydrological landscape analysis in catchments with topographically driven groundwater tables.
\end{abstract} (C) 2009 Elsevier B.V. All rights reserved.

\section{Introduction}

The spatial pattern of saturated areas, including wetlands and lakes, is a key characteristic of boreal landscapes and a factor controlling variables such as stream water quality (Ågren et al., 2007; Cory et al., 2006), land-atmosphere feedback mechanisms (Nilsson et al., 2008) and landscape ecology (Petrin et al., 2007; Serrano et al., 2008). Manual mapping of soil moisture patterns is costly, labor-intensive, and not feasible at large scales. Remote sensing approaches are often useful, but difficult to apply in forested landscapes (Creed et al., 2003), limited to the upper most soil layer and usually require calibration when mapping soil moisture (Houser et al., 1998).

Topography provides an alternative for mapping wetlands and spatial patterns of wetness in catchments where the assumption that groundwater tables basically follow topography holds (Haitjema and Mitchell-Bruker, 2005). The topographic wetness index (TWI) (Beven and Kirkby, 1979) relates upslope area as a measure

\footnotetext{
* Corresponding author. Tel.: +46 867478 66; mobile: +46 7680242 24; fax: +46 8164818.

E-mail address: thomas.grabs@natgeo.su.se (T. Grabs).
}

of water flowing towards a certain point, to the local slope, which is a measure of subsurface lateral transmissivity. The TWI has become a popular and widely used way to infer information about the spatial distribution of wetness conditions (i.e. the position of shallow groundwater tables and soil moisture). On the other hand, the TWI is static and relies on the assumption that local slope, $\tan (\beta)$, is an adequate proxy for the effective downslope hydraulic gradient which is not necessarily true in low relief terrain. In flat terrain, the local slope has a tendency to overestimate the downslope hydraulic gradient due to the effect of downslope water tables. The TWI concept is also less suitable in flat areas because of rather undefined flow directions which are more likely to change over time. In situations where meteorological and hydrological data are available in addition to a digital elevation model (DEM), a more dynamic approach might be useful. Distributed hydrological models allow dynamic simulations of spatially distributed water storage that can be used to derive alternative wetness indices. These model-based wetness indices (MWIs) account, unlike the static TWI, for dynamic influences of upstream and downstream conditions. Thus, they are also applicable in flat terrain where groundwater gradients can be significantly different from ground surface slopes. 
Several studies have discussed the TWI concept and its underlying assumptions (Barling et al., 1994; Seibert et al., 2002) as well as the need for an improved representation of downslope effects and variable contributing areas. For instance, Crave and Gascuel-Odoux (1997) point out the importance of downslope topographic conditions for the spatial distribution of surface wetness, which was one of the motivations for Hjerdt et al. (2004) to develop a downslope index that better represents local groundwater gradients. Barling et al. (1994) and Borga et al. (2002) focus on the size of the effective upslope contributing areas. They introduce a 'quasi-dynamic' wetness index for a better estimation of upslope contributing areas under non-steady state conditions (Barling et al., 1994; Borga et al., 2002). The idea of deriving MWIs from the state variables of a dynamic distributed hydrological catchment model is to find an alternative approach that integrates the effects of downslope controls and variable upslope contributing area. In principle, any moisture-related, spatially-distributed state variable of a catchment model can be used to derive dynamic wetness indices by temporal aggregation.

Important characteristics of simulated time series can be described by statistical moments. As an example, one can compute both mean and standard deviation of simulated, distributed groundwater levels. In this paper, we focus on the comparison of MWIs with the TWI and, thus, we use only MWIs that were computed as long-term averages of simulated groundwater levels.

The objective of this study is to evaluate different MWI and TWI variants by assessing their ability to predict the patterns of saturated areas in a boreal catchment. Saturated areas represent the extreme end of the landscape wetness spectrum and, thus, spatial patterns of saturated areas provide an opportunity for evaluating different methods for mapping not only saturated areas but also landscape wetness in general. The underlying assumption is that a method that represents well the extreme end of the wetness spectrum might also work well at drier locations (Rodhe and Seibert, 1999).
We used two different distributed hydrological models (Grabs et al., 2007) to derive two MWIs from dynamic model simulations as well as from a steady-state MWI ( $\left.\mathrm{MWI}_{\text {steady }}\right)$. The latter was based on a distributed model but in this case, the model is run using temporally constant meteorological forcing. For comparison, we computed the TWI in two different ways. This allowed us to answer a number of questions: Can model-based wetness indices (MWIs) provide significantly better results than the standard TWI? How does the effect of using MWIs to predict wetlands compare to the effect of using different algorithms for computing TWI? How do dynamic MWIs compare to a steady-state MWI that does not require detailed meteorological forcing data and still allows overcoming the limitations of TWI?

\section{Material and methods}

\section{Study site and measurements}

The study was conducted on the upper $67 \mathrm{~km}^{2}$ of the Krycklan catchment $\left(64^{\circ} 14^{\prime} \mathrm{N}, 19^{\circ} 46^{\prime} \mathrm{E}\right)$ in northern Sweden. The catchment ranges from 126 to $369 \mathrm{~m}$ above sea level and is underlain by poorly weathered gneissic bedrock. In the upper part of the catchment, above the highest post-glacial coast line, glacial till deposits up to $10 \mathrm{~m}$ deep were left by the last glaciation. Below the highest post-glacial coast line, coarse-grained glaciofluvial deposits and fine-grained silty or sandy sediments have allowed the streams to form deeply incised channels that efficiently drain the surrounding landscape. Wetlands, which are generally sphagnum-dominated, have formed mainly in areas with flat, drainage-limiting topography and cover about $9 \%$ of the catchment area (Buffam et al., 2007). The most common soils in the catchment are welldeveloped iron podsols. Along the stream network, histic soils or gleysoils can be found. Most of the landscape is forested with Scots pine (Pinus sylvestris). Deciduous trees such as birch (Betula spp.) or alder (Alnus incana) are found in wetlands and along streams, while

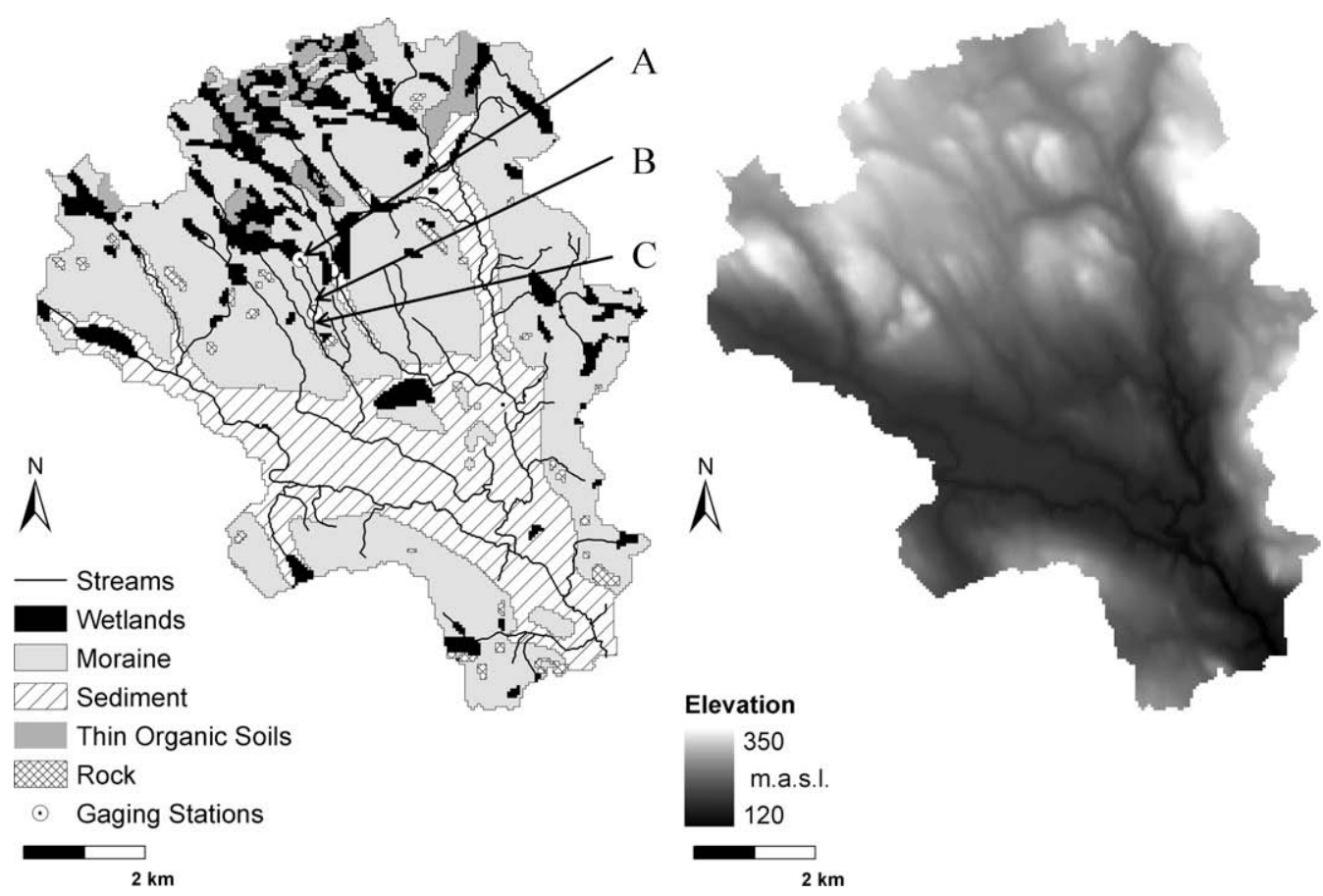



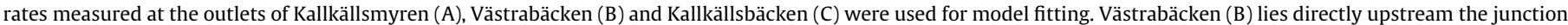

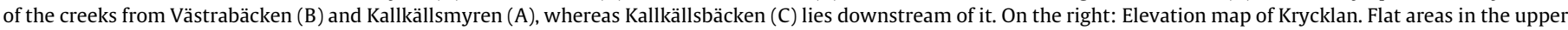
part can be distinguished as patches with relatively uniform grey shades. 
spruce trees (Picea abis) usually grow in the transition zones between riparian soils and podsols. For forestry purposes, many small streams were deepened and additional ditches built during the last century to improve soil drainage. The forest became a research area in 1923; a field station and gauging station were built in 1979 when expanded climate measurements were started. Stream flow, soil hydraulic properties as well as water table and soil moisture variations have been monitored in the $0.5 \mathrm{~km}^{2}$ Kallkällsbäcken sub-catchment since 1980 (Bishop et al., 1990; Kohler et al., 2008). Stream flow is also monitored at two internal gaging stations of Kallkällsbäcken (Fig. 1), Västrabäcken and Kallkällsmyren. Västrabäcken is completely covered by forest, while Kallkällsmyren and Kallkällsbäcken are forested mixed with $40 \%$ and 15\% wetlands, respectively.

Annual precipitation averages $600 \mathrm{~mm}$, and the annual mean air temperature is $1{ }^{\circ} \mathrm{C}$. Approximately one third of the annual precipitation falls as snow (Ottosson Löfvenius et al., 2003) and there are on average 172 days of snow cover before spring runoff begins in April or May.

The spatial distribution of wetlands was determined from a quaternary deposits coverage map $(1: 100,000$, Geological Survey of Sweden, Uppsala, Sweden) (Fig. 1). Laudon et al. (2007) compared areas marked as peat in the quaternary deposits coverage map with areas marked as wetlands in a land cover map (1:12,500, Lantmäteriet, Gävle, Sweden) and found that the areas were almost identical and highly correlated $\left(r^{2}=0.98\right.$, $p<0.0001$ ). A few small lakes surrounded by wetlands were also classified as saturated areas. These areas are predominantly present in the upper, flat till part of the catchment.

\section{Wetness indices}

The wetness indices used in this study are based on the assumption that surface topography is the main controlling factor of groundwater table depths and flowpaths. In many cases, other factors such as subsurface topography (Freer et al., 1997) or hydrogeological characteristics of the aquifer (Haitjema and MitchellBruker, 2005) also need to be considered. In the studied catchment, the basic prerequisites for relating groundwater levels to topography are fulfilled for the upper, moraine part of the catchment. In the lower, sedimentary part surface topography is a less important factor due to the hydrogeological characteristics. Therefore, the latter area was excluded from the analysis in this paper. For the upper part of the catchment ( $68 \%$ of the entire catchment area), five different wetness indices were calculated and compared to mapped wetlands. Three of these indices, the MWIs, were derived from two distributed hydrological models while the other two represent different variants for calculating the TWI (Fig. 2).

The simulations for generating the MWIs are based on two spatially distributed versions of the conceptual HBV model (Bergström, 1976, 1995) using a $50 \mathrm{~m} \times 50 \mathrm{~m}$ raster. In this model, the computations are performed for grid cells, and lateral groundwater flow is computed based on local, time-variant gradients. Both versions compute lateral flows based on Darcy's law using hydraulic gradients, which is a pre-requisite for this study. The first version relies on the traditional HBV concept, while the second is a modified version of the HBV model where saturated and unsaturated soil storages are coupled (Seibert and McDonnell, 2002; Seibert et al., 2003). The coupling of these storages allows a more realistic simulation of water tables and soil moisture in wetlands or at other locations characterized by near-surface groundwater.

Both models were calibrated against discharge data for the period from 6 April 2003 to 30 September 2004 for two subcatchments of Kallkällsbäcken (Fig. 1) and compared against flow measured at the outlet of Kallkällsbäcken (Grabs et al., 2007). All model simulations relied on spatially uniform parameters and inputs. Temperature and precipitation inputs were also adjusted to changes in elevation using lapse rates $\left(-0.6^{\circ} \mathrm{C} / 100 \mathrm{~m}\right.$ for temperature and $+10 \% / 100 \mathrm{~m}$ for precipitation). Spatial variations of simulated groundwater storages were thus solely controlled by topography. After calibration, the models were applied to the entire Krycklan catchment, and the model simulations of spatially distributed values were used to derive MWIs. The derived MWIs were only evaluated in portions of the catchment that are similar in terms of till and wetland coverage to the subcatchments used for calibration. The hydrologically dissimilar sedimentary portions of the catchment were excluded from the analysis. There are several possibilities to aggregate the time series into a single value for each grid cell. In this study, the MWIs were calculated as normalized annual average values of simulated water storage in the saturated zone of the soil column.

The MWI derived from the distributed HBV model is termed $\mathrm{MWI}_{\mathrm{hbv}}$, while the MWI derived from the modified distributed HBV model is termed $\mathrm{MWI}_{\text {mod. }}$. Furthermore, a steady-state wetness index $\left(\mathrm{MWI}_{\text {steady }}\right)$ was computed by applying a constant net rainfall rate of $1 \mathrm{~mm}$ per day to the calibrated version of the modified HBV model. Unlike the TWI, the $\mathrm{MWI}_{\text {steady }}$ does not rely on the assumption that groundwater flow exactly follows the surface topography. In comparison with the MWIs, the conceptualization of the coupling of the saturated and unsaturated zones does not influence the result since, at steady state, there is no dynamic interaction between these zones (i.e., groundwater levels are constant in time). Most importantly, the $\mathrm{MWI}_{\text {steady }}$ is derived from a model in steady-state and has no time-varying component. Hence, the comparison of the $\mathrm{MWI}_{\text {steady }}$ to the other indices distinguishes the importance of downslope controls from the benefit of running the model with temporally varying forcing data.

For comparison, we also computed the TWI values. The TWI at a certain point in the catchment is defined as the upslope area per unit contour length, $a_{s}$, divided by the local gradient, $\tan \beta$ (Eq. (1)).

$\mathrm{TWI}=\ln \left(a_{s} / \tan (\beta)\right)$



Fig. 2. Overview over the different wetness indices. 
There are different algorithms to compute TWI distributions (Sørensen and Seibert, 2007). In this study, we applied the widely used multidirectional flow algorithm as proposed by Quinn et al. (1991) (TWI $\mathrm{MD}_{\mathrm{M}}$ ), and a new flow algorithm which was recently suggested by Seibert and McGlynn (2007) $\left(\mathrm{TWI}_{\mathrm{MD} \infty}\right)$. The latter algorithm is an extension of the method of Tarboton (1997) and uses triangular facets to calculate the downslope routing of the accumulated area. In addition, for computing $\mathrm{TWI}_{\mathrm{MD} \infty}$, the local gradients, $\tan \beta$, were replaced by the downslope index suggested by Hjerdt et al. (2004) as a better approximation of local groundwater gradients.

\section{Evaluation of wetness indices}

In this study, we evaluated the performance of the different wetness indices based on their capability to predict the spatial distributions of wetlands. It is important to recognize that spatially uniform parameterizations were used. Therefore, the predicted distribution of wetlands is not caused by spatially varying param- eters but is an emerging property of the model simulation and affected only by topography. The similarity between observed wetlands and patterns produced by the various wetness indices (Figs. 2 and 3) was quantified using different statistical measures. The objective of this comparison was to assess the capacity of the indices to predict the geographic position of the wetland and their ability to generate a clear contrast between wetland and surrounding areas as well as their capacity to reproduce the landscape topology of the observed wetlands. Prior to these analyses, the wetness index maps were reclassified into binary maps ('wetland', 'no wetland'). Specific threshold values were used for this reclassification. The threshold was chosen so that the estimated wetland percentage equaled the percentage of observed wetlands. As mentioned before, the sedimentary zones of the catchment were excluded, which reduced the actual study area from $67 \mathrm{~km}^{2}$ to $47.4 \mathrm{~km}^{2}$, of which $13.4 \%$ was wetland. Each grid cell for which the wetness index value belonged to the highest $13.4 \%$ values of the distribution is assigned a value of 1 ('wetland'), all other grid cells were set to 0 ('no wetland') (Fig. 3 ).
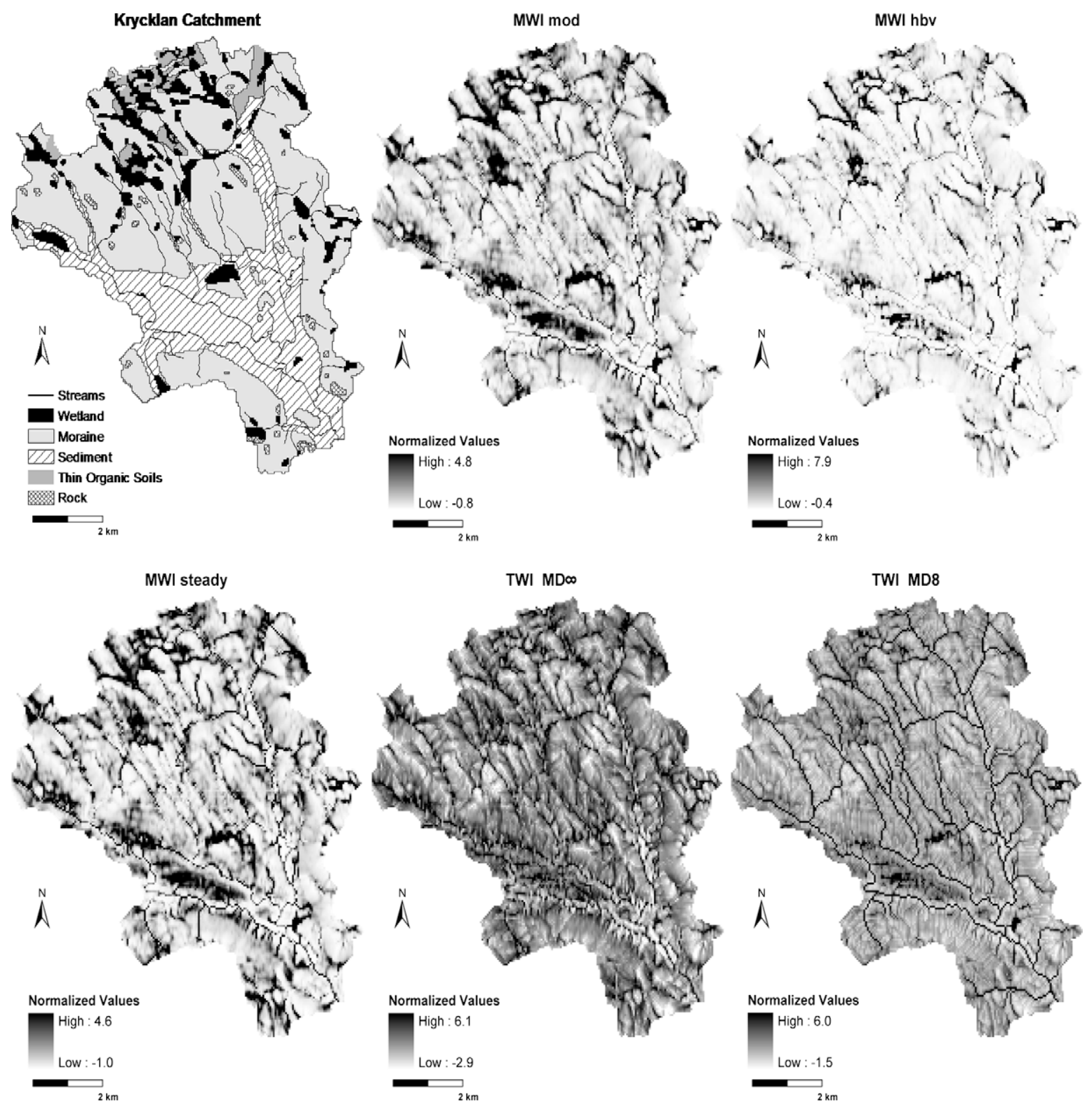

Fig. 3. Maps with normalized values of TWI and MWI indices. Areas that are predicted to be wet are dark, while light areas are predicted to be relatively dry. 
Table 1

Confusion matrix showing the number of agreements (yes-yes, a; no-no, d) and disagreement (yes-no, c; no-yes, b) for predicted ( $\left.W_{\text {predicted }}\right)$ and observed wetlands ( $\left.W_{\text {observed }}\right)$.

\begin{tabular}{lll}
\hline & $W_{\text {predicted }}$ & \\
\cline { 2 - 3 } & Yes & No \\
\hline$W_{\text {observed }}$ & & \\
Yes & $a$ & $b$ \\
No & $c$ & $d$ \\
\hline
\end{tabular}

There is no generally accepted, single method to compare raster maps with binary data. Wealands et al. (2005) provide a review of different approaches for comparing spatial patterns. In this study, we evaluated the various indices using three similarity coefficients comprising a measure of direct spatial coincidence (SC), the simple-matching coefficient (SM) and Cohen's kappa statistic of agreement $(\kappa)$ (Table 2). These indices represent different ways of weighing spatial agreement and disagreement when comparing raster maps cell-by-cell. The results of the cell-by-cell comparison are summarized in a confusion matrix (Table 1 ), which provides the basis for the calculation of the similarity coefficients Although we consider $\kappa$ to be the most suitable measure, the SC and SM coefficients are also presented because these were already used, although under different names, in previous studies (Creed et al., 2003; Dahlke et al., 2005; Güntner et al., 2004; Rodhe and Seibert, 1999).

It is noteworthy that in contrast to all other measures, Cohen's kappa $(\kappa)$ also accounts for the part of the agreement due to chance, i.e. the part of agreement that could be achieved by any random predictor. The chance-correction is accomplished by subtracting the expected agreement, $(\hat{a}+\hat{d})$ (Eq. (2)), from the actual agreement, $(a+d)$. The calculation of actual and expected agreement is based on coefficients from the confusion matrix (Table 1).

$(\hat{a}+\hat{d})=\frac{a+b}{m} \cdot(a+c)+\frac{b+d}{m} \cdot(c+d)$

The $\kappa$-scores were also compared pairwise to test whether two wetness indices differ significantly (Sheskin, 2003). In practice, this allows for a more objective judgment about the actual ranking even in cases where two wetness indices have very similar $\kappa$ scores.

The Kolmogorov-Smirnov measure $\left(d_{\mathrm{KS}}\right)$ can be used to assess the capacity of different wetness indices to separate wetlands from surrounding non-wetland areas (Rodhe and Seibert, 1999). Unlike the previous indices, the $d_{\mathrm{KS}}$ is a global performance measure that does not involve spatial aspects. The $d_{\mathrm{KS}}$ represents the maximal distance between two empirical cumulative distribution functions (ECDFs) (Sheskin, 2003). The first ECDF contains only wetness index values from observed wetlands, whereas the second ECDF contains wetness index values from all other areas. For two identical ECDFs the $d_{\mathrm{KS}}$ is zero; for two completely non-overlapping ECDFs the $d_{\mathrm{KS}}$ value equals one. The idea behind this is that a good wetness index separates wetlands from surrounding non-wetland areas more clearly than a bad wetness index. Given an ideal map of observed wetlands and a perfect wetness index, the value of $d_{\mathrm{KS}}$ would be one.

Wetlands and lakes are distinct landscape units that might have an important influence on stream chemistry as well as on landscape and stream ecology. Topological aspects such as fragmentation, size and proximity determine, to a large degree, the actual interaction between saturated areas and other landscape elements. Thus, it is important to know how well different wetness indices are able reproduce the observed landscape structure. In this study, we used the freely available FRAGSTAT software package (McGarigal and Marks, 1995) to calculate the total number of individual patches, $N$, as well as the area-weighted means of patch area, $A_{\mathrm{a}-\mathrm{w}}$ (Eqs. (3) and (4)). Grid cells were considered to belong to the same individual patch when they were neighboring in one of the four cardinal directions, while grid cells only connected in a diagonal direction were considered to belong to different patches.

(i) $A_{\mathrm{a}-\mathrm{w}}=\sum_{i=1}^{N} \omega_{i} \cdot A_{i}$

(ii) $\omega_{i}=\frac{A_{i}}{\sum_{i=1}^{N} A_{i}}$

\section{Results}

The different indices corresponded to varying degrees with the observed wetlands. The general ranking of the wetness indices was the same regardless of the chosen similarity coefficient (Table 3 ). This result could be expected because all the coefficients are derived from similar quantities (Tables 1 and 2).

The indices achieved SC and SM scores that compare well with similar studies (Creed et al., 2003; Dahlke et al., 2005; Güntner et al., 2004; Rodhe and Seibert, 1999). The MWI variants were in better agreement with the observed wetlands than the TWI. Of

Table 2

An overview of the applied similarity coefficients and their theoretical range. Negative values of Cohen's kappa $k$ indicate that the observed spatial agreement is less than the spatial agreement that a random predictor would achieve. In practice, however, one usually expects $\kappa$ to fall in the interval between zero and one. The coefficients refer $t$, the quadrants of the confusion matrix (Table 1), and the variable " $m$ ", the total number of grid cells, i.e. $m=a+b+c+d$.

\begin{tabular}{lll}
\hline Coefficient & Expression & Range \\
\hline SC (spatial coincidence) & $\frac{a}{a+b}$ & {$[0,1]$} \\
SM (simple matching) & $\frac{a+d}{m}$ & {$[0,1]$} \\
$\kappa$ (Cohen's kappa) & $\frac{(a+d)-(\hat{a}+\hat{d})}{m-(\hat{a}+d)}$ & {$[-\infty, 1]$} \\
\hline
\end{tabular}

Table 3

Quantitative performance measures describing the fit between predicted and observed wetlands. Higher values indicate a better performance. The rank of the different wetness indicators is established by arranging all performance measures in decreasing order. SC is the percentage of correctly predicted wetlands relative to the totally observed wetlands, SM is the simple matching coefficient and $k$ is the kappa coefficient of agreement.

\begin{tabular}{lllll}
\hline & Rank & SC & SM & $\kappa$ \\
\hline MWI $_{\text {mod }}$ & 1 & 0.56 & 0.88 & 0.49 \\
MWI $_{\text {steady }}$ & 2 & 0.53 & 0.87 & 0.46 \\
MWI $_{\text {hbv }}$ & 3 & 0.52 & 0.87 & 0.44 \\
TWI $_{\text {MD } \infty}$ & 4 & 0.50 & 0.87 & 0.42 \\
TWI $_{\text {MD8 }}$ & 5 & 0.49 & 0.86 & 0.41 \\
\hline
\end{tabular}

Table 4

Significance of the pairwise comparison of $\kappa$-scores achieved by different dynamic and topographic wetness indices. Cases where the alternative hypothesis $\mathrm{H}_{1}$ : $\kappa_{\text {row }}>\kappa_{\text {column }}$ is supported with a confidence level of $95 \%$ are marked with a "+". Cases where the higher ranked index (first column) does not perform significantly better than the lower ranked index (first row) are marked with a "0". For example, the $\mathrm{MWI}_{\mathrm{hbv}}$ index (line 3) does not perform significantly better than the $\mathrm{TWI}_{\mathrm{MD} \infty}$ index (column 3 ) even though the $\kappa$-score of $\mathrm{MWI}_{\mathrm{hbv}}$ is higher than the $\kappa$-score of the $\mathrm{TWI}_{\mathrm{MD} \infty}$ index.

\begin{tabular}{lllll}
\hline & $\mathrm{MWI}_{\text {steady }}$ & $\mathrm{MWI}_{\text {hbv }}$ & $\mathrm{TWI}_{\mathrm{MD} \infty}$ & $\mathrm{TWI}_{\mathrm{MD} 8}$ \\
\hline $\mathrm{MWI}_{\text {mod }}$ & + & + & + & + \\
$\mathrm{MWI}_{\text {steady }}$ & & 0 & + & + \\
$\mathrm{MWI}_{\text {hbv }}$ & & & 0 & + \\
$\mathrm{TWI}_{\mathrm{MD} \infty}$ & & & & 0 \\
\hline
\end{tabular}


Table 5

Values of the Kolmogorov-Smirnov $D\left(d_{\mathrm{ks}}\right)$ statistic describing how clearly an index separates wetlands from non-wetlands.

\begin{tabular}{llllll}
\hline & $\mathrm{MWI}_{\text {mod }}$ & $\mathrm{MWI}_{\text {steady }}$ & $\mathrm{MWI}_{\text {hbv }}$ & $\mathrm{TWI}_{\mathrm{MD} 8}$ & $\mathrm{TWI}_{\mathrm{MD} \infty}$ \\
\hline$d_{\mathrm{KS}}$ & 0.58 & 0.58 & 0.54 & 0.52 & 0.51 \\
\hline
\end{tabular}

the MWI indices, the dynamic index based on the modified distributed HBV model $\left(\mathrm{MWI}_{\text {mod }}\right)$ performed best, the steady-state $M W I_{\text {steady }}$ index was the second best, followed by the dynamic index based on the distributed HBV model ( $\left.\mathrm{MWI}_{\mathrm{hbv}}\right)$.

The $\kappa$-scores were used to test whether the scores from a pair of wetness indices differ significantly (Sheskin, 2003). A test score was calculated for every possible combination of two wetness indices and then compared to the 0.05 standard $z$-scores (Table 4). $\mathrm{MWI}_{\text {mod, }}$ which was the highest ranked index, was found to have
Table 6

Results of the landscape structure analysis performed with the FRAGSTAT software. The table shows the total number of distinct wetland patches, $N$, as well as the areaweighted means of the patch-size, $A_{\mathrm{a}-\mathrm{w}}$.

\begin{tabular}{llc}
\hline & $N$ & $A_{\mathrm{a}-\mathrm{w}}$ (ha) \\
\hline Wetlands & 157 & 23.0 \\
MWI $_{\text {mod }}$ & 292 & 30.3 \\
MWI $_{\text {steady }}$ & 328 & 16.6 \\
MWI $_{\text {hbv }}$ & 329 & 15.4 \\
TWI $_{\text {MD } \infty}$ & 565 & 4.7 \\
TWI $_{\text {MD8 }}$ & 592 & 11.4 \\
\hline
\end{tabular}

a significantly higher $\kappa$-score than all other indices. $\mathrm{TWI}_{\mathrm{MD} \infty}$ and $\mathrm{TWI}_{\mathrm{MD} 8}$ did not perform as well. Based on the analysis in this study, the different approaches to compute TWI did not provide significantly different results.

Evaluating the discriminatory strength of the indices using the $d_{\mathrm{KS}}$ statistic resulted in largely the same ranking of the wetness
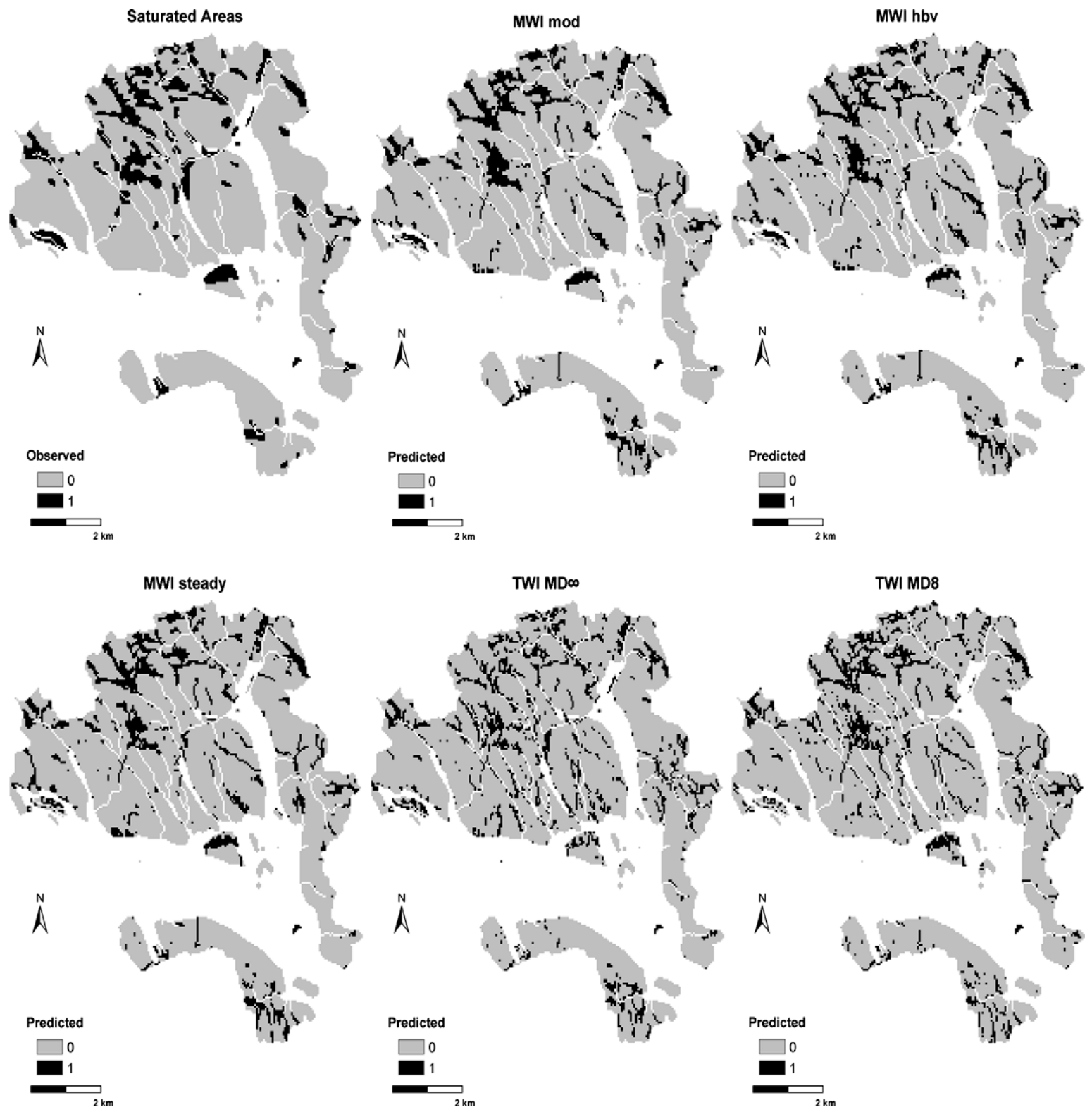



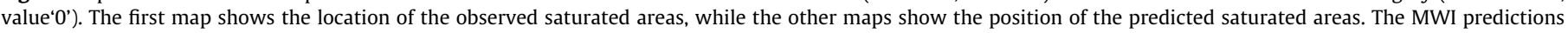
appear visually more similar to the observed saturated areas than the more fragmented TWI predictions. 



$2 \mathrm{~km}$

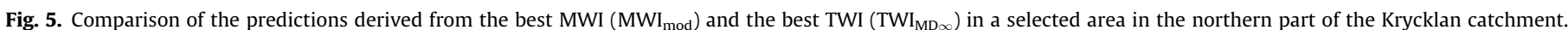

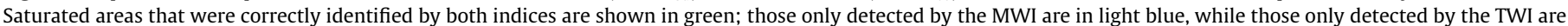

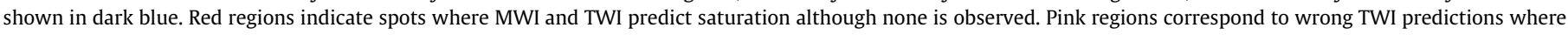
MWI predictions are correct. Yellow areas indicate wrong MWI predictions where TWI predictions are correct.

index performance as the similarity coefficients. The two variants of TWI, however, switched positions (Table 5). Tests of significance demonstrated that all $d_{\mathrm{KS}}$ were significantly different from zero.

The analysis of the landscape patterns predicted by each of the indices revealed that all indices tend to generate a greater number of wetland patches than were actually observed (Table 6). While it is likely that a number of wetlands are not represented in the maps, these results suggest that the fragmentation of wetlands is overestimated; this overestimation was especially large for the wetland predictions based on TWI (Fig. 5).

\section{Discussion}

MWIs derived as the long-term average of groundwater levels (or saturated storage volumes) simulated by a distributed catchment model predicted the position of saturated areas better than the static TWI. The $\mathrm{MWI}_{\text {mod }}$ index, which was based on a process-oriented conceptualization of the saturated-unsaturated zone interactions, performed significantly better than all other indices. The $\mathrm{MWI}_{\mathrm{hbv}}$ index, which was based on the original HBV model and, thus, a simplified representation of the unsaturated zone, did not perform as well as the $\mathrm{MWI}_{\text {mod }}$ index but about as equally well as the $\mathrm{MWI}_{\text {steady }}$ index, which was based on steady-state simulations Fig. 4.

As expected, the largest differences between TWI and MWI predictions were found in flat areas, where the ground surface may not be appropriate to describe local subsurface flow. In these situations, differences in water storage, and therefore depth to water table, between grid cells significantly influence local gradients and flow directions.

In areas that drain into wetlands, the hydraulic gradient is usually smaller than the surface slope. Thus, the static TWI, which relies on the terrain slope, has a tendency to underestimate the degree of wetness in these areas. This leads to an underestimation of the actual extent of connected saturated areas or wetlands (Fig. 3). Moreover, uncertain flow directions can result in unrealistic values of specific upslope area in flat regions. If the downslope routing of upslope area is channelized more or less by chance in flat areas, unrealistic spatial differences within small distances can be caused and spatial heterogeneity is artificially introduced. This produces significantly more fragmentized saturated patches when using TWI compared with MWI (Fig. 5). The good performance of the $\mathrm{MWI}_{\text {steady }}$ index compared with the TWI thus illustrates the benefits of simulated hydraulic gradients and dynamic flow routing compared to terrain slope and static flow routing.

The significance test of the $d_{\mathrm{KS}}$ value is, unlike the significance test of Cohen's $\kappa$, less suitable for further interpretation because the null-hypothesis $\left(d_{\mathrm{KS}}=0\right)$ can almost always be rejected when there is a large number of observations. The $\mathrm{TWI}_{\mathrm{MD}}$ index generates a stronger contrast between saturated and unsaturated areas than the static $\mathrm{TWI}_{\mathrm{MD} \infty}$ index. This is surprising because at the same time the $\mathrm{TWI}_{\mathrm{MD} 8}$ index is less accurate than the $\mathrm{TWI}_{\mathrm{MD} \infty}$ index when predicting the location and structure of wetlands. A 
higher discriminatory strength of an index therefore does not imply good performance according to the other tested quality measures. For these reasons the $d_{\mathrm{KS}}$ statistic, although used in a previous study (Rodhe and Seibert, 1999), does not seem to be a suitable measure in this type of application.

The size and number of landscape elements are topological measures and therefore useful to assess the performance of the wetness indices in a different way compared to the previously described performance measures. As discussed earlier, the static TWI had a tendency to underestimate the extent and contiguity of wetlands. This resulted in smaller and more fragmented wetland patches, i.e., the average area, $A_{\mathrm{a}-\mathrm{w}}$, was smaller and the number of wetland patches, $N$, was larger. Based on these rather clear results, one can assume that other pattern measures, which might be more appropriate in other applications, would also be affected by the limitations of most indices to reproduce the observed landscape patterns.

Topographic indices depend on the quality and resolution of the DEM from which they were derived (Beven, 1997; Sørensen and Seibert, 2007), while benchmarking their ability to reproduce observed wetland patterns is clearly influenced by the accuracy and completeness of the observed wetlands used for benchmarking (Creed et al., 2003). Hence, it is likely that better input data would affect the performances of the wetness indices but it remains difficult to predict in which way the results would change. For example, an increased resolution of the DEM does not necessarily lead to better performance because groundwater flow is less likely to follow small-scale topography. The traditional TWI is, theoretically, more sensitive to scale-effects than the MWIs that account for downslope controls. Particularly at high resolutions, micro-topographic features can lead to highly variable terrain slope values, which are unrealistic estimates of hydraulic gradients. Such features will be smoothed out by calculating groundwater storages and hydraulic gradients between grid cells. The choice of a MWI instead of the TWI is therefore attractive when working with high-resolution data, but it also requires considerably more computer resources.

The main questions addressed in this study do not depend on the absolute performances of the indices but rather on their ranking. It is therefore crucial to assess the robustness of the established ranking. The pairwise comparison of the $\kappa$-scores (Table 4) allows such a qualitative assessment of the robustness of the ranking. Pairs of indices with significantly different $\kappa$-scores are less likely to switch their position than pairs whose $\kappa$-scores are not significantly different.

The choices in the conceptualization of hydrological process greatly influence the derived model-based wetness indices. The MWI maps are dependent on the catchment model (including its parameterization) used to simulate the spatially distributed state variables. The differences between the $\mathrm{MWI}_{\text {mod }}$ and $\mathrm{MWI}_{\mathrm{hbv}}$ indices indicate the effect of using different models. However, both indices and the steady-state $\mathrm{MWI}_{\text {steady }}$ index performed considerably better than the TWI. Linking the TWI to spatial patterns of wetness implicates a simplified conceptualization of hydrological processes, which, as shown here, can significantly influence the results. Replacing the TWI concept with a distributed hydrological model is therefore a tradeoff between process representation and parameter parsimony. We believe that relatively simple, conceptual, distributed models, similar to the ones used in this study, are a good compromise between these two opposing goals.

\section{Conclusions}

The different topography-based indices were evaluated based on their ability to predict observed wetlands. For the TWI, these predictions were directly derived from topography, whereas for
MWIs these predictions were derived from spatial variations caused only by topography. In other words, the spatial distribution of predicted wetland was an emerging feature rather than an effect of a spatially varying parameterization. The various indices were able to predict the distribution of observed wetlands although there were clear differences in performance. The model-based MWIs generally outperformed the TWI. In addition, the steadystate wetness index $\left(\mathrm{MWI}_{\text {steady }}\right)$ that, unlike the other MWIs, does not require detailed meteorological input data performed better than the TWI.

While this paper focuses on the comparison of MWIs with the TWI and, thus, uses only long-term averages of the distributed model simulations, we wish to emphasize the potential to derive other indices using different ways of temporal aggregation of the model simulations. Measures such as the standard deviation, mean values during shorter periods, or change rates might provide useful information. The index approach allows capturing essential spatial characteristics in a more efficient way than using model simulations directly. In this study, we demonstrated that the application of a catchment model allows better use of topographic data than the static TWI. These results encourage further work on modelbased indices to describe spatially variable hydrologic conditions.

\section{References}

Ågren, A., Buffam, I., Jansson, M., Laudon, H., 2007. Importance of seasonality and small streams for the landscape regulation of DOC export. Journal of Geophysical Research G: Biogeosciences 112, G03003. doi:10.1029/ 2006JG000381.

Barling, R.D., Moore, I.D., Grayson, R.B., 1994. A quasi-dynamic wetness index for characterizing the spatial distribution of zones of surface saturation and soil water content. Water Resources Research 30 (4), 1029-1044.

Bergström, S., 1976. Development and application of a conceptual runoff model for Scandinavian catchments. Department of Water Resources Engineering, Lund Institute of Technology, University of Lund.

Bergström, S., 1995. The HBV model. Computer Models of Watershed Hydrology $443,476$.

Beven, K., 1997. TOPMODEL: a critique. Hydrological Processes 11 (9), 1069-1085.

Beven, K., Kirkby, M., 1979. A physically based, variable contributing area model of basin hydrology. Hydrological Sciences Bulletin 24 (1).

Bishop, K.H., Grip, H., O'Neill, A., 1990. The origins of acid runoff in a hillslope during storm events. Journal of Hydrology (Amsterdam) 116 (1), 35-61.

Borga, M., Dalla Fontana, G., Cazorzi, F., 2002. Analysis of topographic and climatic control on rainfall-triggered shallow landsliding using a quasi-dynamic wetness index. Journal of Hydrology 268 (1-4), 56-71.

Buffam, I., Laudon, H., Temnerud, J., Mörth, C.M., Bishop, K., 2007. Landscape-scale variability of acidity and dissolved organic carbon during spring flood in a boreal stream network. Journal of Geophysical Research 112, G01022. doi:10.1029/2006JG000218.

Cory, N., Buffam, I., Laudon, H., Köhler, S., Bishop, K., 2006. Landscape control of stream water aluminum in a boreal catchment during spring flood. Environmental Science \& Technology 40 (11), 3494-3500.

Crave, A., Gascuel-Odoux, C., 1997. The influence of topography on time and space distribution of soil surface water content. Hydrological Processes 11 (2), 203210.

Creed, I.F., Sanford, S.E., Beall, F.D., Molot, L.A., Dillon, P.J., 2003. Cryptic wetlands: integrating hidden wetlands in regression models of the export of dissolved organic carbon from forested landscapes. Hydrological Processes 17 (18), 36293648.

Dahlke, H., Helmschrot, J., Behrens, T., 2005. A GIS-based terrain analyses approach for inventory of wetland in the semi-arid headwaters of the Umzimvubu basin, South Africa. Remote Sensing and GIS for Environmental Studies, Göttinger Geographische Abhandlungen 113, 78-86.

Freer, J. et al., 1997. Topographic controls on subsurface storm flow at the hillslope scale for two hydrologically distinct small catchments. Hydrological Processes 11 (9), 1347-1352.

Grabs, T., Seibert, J., Laudon, H., 2007. Distributed runoff modelling. Wetland runoff and its importance for spring-flood predictions. Elforsk rapport 07:16, Svenska elföretagens forsknings-och utvecklings-Elforsk-AB, Elforsk AB, 10153 Stockholm.

Güntner, A., Seibert, J., Uhlenbrook, S., 2004. Modeling spatial patterns of saturated areas: an evaluation of different terrain indices. Water Resources Research 40 (5), W05114.

Haitjema, H.M., Mitchell-Bruker, S., 2005. Are water tables a subdued replica of the topography? Ground Water 43 (6), 781-786.

Hjerdt, K.N., McDonnell, J.J., Seibert, J., Rodhe, A., 2004. A new topographic index to quantify downslope controls on local drainage. Water Resources Research 40 (5), W05602. 
Houser, P.R. et al., 1998. Integration of Soil Moisture Remote Sensing and Hydrologic Modeling Using Data Assimilation.

Koehler, S.J., Buffam, I., Laudon, H., Bishop, K., 2008. Climate's control of intraannual and interannual variability of total organic carbon concentration and flux in two contrasting boreal landscape elements. Geophysical ResearchBiogeosciences, 113, G03012, doi:10.1029/2007JG000629.

Laudon, H., Sjöblom, V., Buffam, I., Seibert, J., Mörth, M., 2007. The role of catchment scale and landscape characteristics for runoff generation of boreal streams. Journal of Hydrology 344 (3-4), 198-209.

McGarigal, K., Marks, B.J., 1995. FRAGSTATS: Spatial Pattern Analysis Program for Quantifying Landscape Structure. US Department of Agriculture, Forest Service, Pacific Northwest Research Station, Portland, OR.

Nilsson, M., Sagerfors, J., Buffam, I., Laudon, H., Eriksson, T., Grelle, A., Klemedtsson, L., Weslien, P., Linderoth, A., 2008. A. Complete carbon budgets for two years of a boreal oligotrophic minerogenic mire. Global Change Biology 14 (1-6), doi: 10.1111/j.1365-2486.2008.01654.x.

Ottosson Löfvenius, M., Kluge, M., Lundmark, T., 2003. Snow and soil frost depth in two types of shelterwood and a clear-cut area. Scandinavian Journal of Forest Research 18 (1), 54-63.

Petrin, Z., McKie, B., Buffam, I., Laudon, H., Malmqvist, B., 2007. Landscapecontrolled chemistry variation affects communities and ecosystem function in headwater streams. Canadian Journal of Fisheries and Aquatic Sciences 64 (11), 1563-1572.

Quinn, P., Beven, K., Chevallier, P., Planchon, O., 1991. The prediction of hillslope flow paths for distributed hydrological modelling using digital terrain models. Hydrological Processes 5 (1), 59-79.

Rodhe, A., Seibert, J., 1999. Wetland occurrence in relation to topography: a test of topographic indices as moisture indicators. Agricultural and forest meteorology $98,325-340$
Seibert, J., Bishop, K., Rodhe, A., McDonnell, J., 2002. Groundwater dynamics along a hillslope: a test of the steady state hypothesis. Water Resources Research 39 (1), 1014. doi:10.1029/2002WR001404.

Seibert, J., McDonnell, J.J., 2002. On the dialog between experimentalist and modeler in catchment hydrology: use of soft data for multicriteria model calibration. Water Resources Research 38 (11), 1241. doi:10.1029/ 2001WR000978.

Seibert, J., McGlynn, B.L., 2007. A new triangular multiple flow-direction algorithm for computing upslope areas from gridded digital elevation models, Water Resources Research 43, W04501. doi:10.1029/ 2006WR005128.

Seibert, J., Rodhe, A., Bishop, K, 2003. Simulating interactions between saturated and unsaturated storage in a conceptual runoff model. Hydrological Processes 17 (2), 379-390.

Serrano, I., Buffam, I., Palm, D., Brännäs, E., Laudon, H., 2008. Thresholds for survival of brown trout (Salmo trutta L.) embryos and juveniles during the spring flood acid pulse in DOC-rich streams. Transactions of the American Fisheries Society 137, 1363-1377.

Sheskin, D.J., 2003. The Handbook of Parametric and Nonparametric Statistical Procedures. Chapman \& Hall/CRC.

Sørensen, R., Seibert, J., 2007. Effects of DEM resolution on the calculation of topographical indices: TWI and its components. Journal of Hydrology 347 (1-2), 79-89.

Tarboton, D.G., 1997. A new method for the determination of flow directions and upslope areas in grid digital elevation models. Water Resources Research 33 (2), 309-319.

Wealands, S.R., Grayson, R.B., Walker, J.P., 2005. Quantitative comparison of spatial fields for hydrological model assessment-some promising approaches. Advances in Water Resources 28 (1), 15-32. 